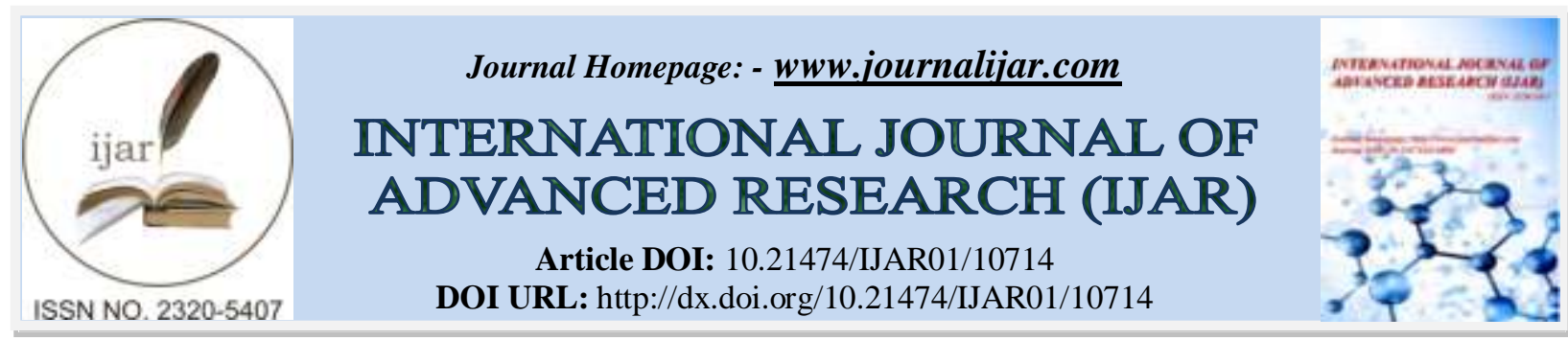

RESEARCH ARTICLE

\title{
ACADEMIC STAFFS PERCEPTIONS TOWARD PERFORMANCE APPRAISAL SYSTEM IN HIGHER EDUCATION (CASE OF SAMARA UNIVERSITY)
}

Getu Eshetu Taddese

Lecturer, Department of Management, College of Business and Economics, Samara University, Ethiopia.

\section{Manuscript Info}

Final Accepted: 25 February 2020

Published: March 2020

Keywords:-

Performance Appraisal System, Academic Staffs, Perception of Performance Appraisal
Manuscript History

Received: 22 January 2020

\begin{abstract}
Effective performance appraisal system in higher education institution would lead to the growth and development of its academic staffs if implemented properly and perceived by the staffs that it creates benefits to them. The purpose of this study was to explore academic staffs of the Samara University perceptions toward performance appraisal system with the aim to identify trends and areas for further improvements. For the purpose of this study descriptive research design was employed. The researcher used stratified random sampling to stratify all participants into seven colleges and one school of law. Of 968 academic staffs, 283 participants having two and more experience of teaching were selected from each stratum proportionally by using purposive sampling to select respondents with desired teaching experience. Both primary and secondary data were collected. Primary data were collected through structured questionnaire from 261 academic staffs having two and more teaching experience in the University which resulted in response rate of $92 \%$, for 261 out of the 283 responded to the distributed questionnaire. Secondary data were collected from previous studies and used as reference. Data was analyzed using descriptive statistics. The study showed that most academic staffs viewed overall performance appraisal system as ineffective and dissatisfied with it .In addition, lack of feedback on regular basis from their departments and dissatisfaction with students' and peer evaluation results were seen as major problems. To improve these problems, the study recommends implementation of effective performance appraisal, providing timely feedback and creating awareness to students and peers regarding the use of performance appraisal.
\end{abstract}

Copy Right, IJAR, 2020,. All rights reserved.

\section{Introduction:-}

The ever-growing emphasis on performance appraisal has been attributed to the fact that it seems impossible for managers to effectively manage any organization without the adequate information on how people are performing, and discharging their expected responsibilities. Such information is necessary for critical management functions like upholding control of current operations and planning for the future, making decisions about training and development, recognitions, compensations and promotions. 
The increasing need for greater accountability and transparency by higher educational institutions has led to a growing emphasis on performance appraisal for academic staffs. Staff appraisal has been considered as a highly important issue that should be effectively embraced by academic professionals as an essential aspect of their job. As well as understanding the effects of performance appraisal also need to have an understanding of how to design more effective systems for performance evaluation. The reason is that wrong performance appraisal system can lead to inaccurate performance appraisals and therefore result in dissatisfaction, poor performance, low motivation, and commitment of academic staffs.

According to Jafari et al. (2009), Performance appraisal is one of the critical human resource practices administered in managing organizations with the aim of answering basic questions such as who is doing what, how well or badly employees are performing, who is efficiently and effectively accomplishing his or her task and who is not, what challenges are being encountered, where and how improvements should be made.

Performance appraisal is an evaluation and acknowledgement of employee performance in discharging their duties and responsibilities (Sonal and Isaac, 2016). It is often considered as one of the most important human resource management functions (Selvarajan and Cloninger, 2008). The goals of performance appraisal is to improve employees' contribution to organizational goals and work performance. A well-designed and implemented performance appraisal system improves the performance of individuals, teams, and the organization as whole. Using regular feedback, employees can better understand what skills they need to develop and also fulfills a basic human need to be recognized and valued, which leads to higher self-esteem and motivation for optimal performance.

Similarly, performance appraisal system can enable managers to better understand their employees' skills and proficiency levels. Through performance appraisal, managers' master understanding of an individual's strengths and weaknesses. If an employee receives constant and high-quality feedback, the employee well become more selfaware of their behaviours and leads to more growth and development.

Despite the fact that the performance appraisal remains the most important human resource function and used for various decision- making by management of an organization, it could be a source of a problem unless properly implemented and employees have a confidence on the appropriateness of the evaluation to make crucial human resource decisions. According to Rasch (2004), most employees have mixed feelings with performance appraisal systems. Whilst some believe it carries some biases and largely fails to meet its objectives, others find it a means to justify their performance. Managers may commit mistakes while evaluating employees' performance. Some of these biases are perceived by employees as ways of unfairly interpreting their performances (Rasch, 2004).

Moreover, workers might not always view performance appraisals as a positive measure (Kuvaas, 2007). When the employees perceive appraisals to be fair, it emits positive attitude and vice versa (Patrick and Ali, 2014).The reaction of employees toward performance appraisal system is considered one of the main factors to evaluate the relevance of appraisal system (Keeping \& Levy, 2000; Levy \& Williams, 2004).

The performance appraisal system cannot be deemed efficient if employees do not see the use of it and its fair and equitable nature (Keeping \& Levy, 2000). Also, Jawahar (2007) indicated that the efficiency of performance appraisal system depends not only on the validity and reliability of the performance appraisal measures but also on the employees' reaction. Nevertheless, the question of employees' reaction to the performance appraisal has been given little attention (Kuvaas, 2011).

Liza (2012) in his study found that major gaps in implementing performance appraisal where lack of appropriate rewards given for high performing employees, the appraisal system was not fully explained to employees and no performance appraisal feedback was provided. Another study by Ambreen et al. (2011) indicated that employees were aware of the useful results of performance appraisal but poorly trained raters, lack of multiple rater and absence of feedback during performance appraisal would make performance appraisal less effective.

According to Aleassa (2014), employee satisfaction with the performance appraisal plays an essential role in their long-term efficiency indicating that a negative reaction toward the performance can spoil the entire appraisal system even if it was built carefully. If employees see the performance appraisal system as unfair, they are less likely to use the feedback from the appraisal to improve their performance. Selvarajan and Cloninger (2011) provided evidence that higher level of perceived fairness and accuracy lead to higher levels of employee satisfaction with performance appraisal by motivating employees to improve performance in the future. 
Besides, Jawahar (2007) stated that the employee reactions towards evaluations have crucial impacts on the evaluation mechanism which could lead to productive employees. It is important to do research on employees' attitude towards performance appraisal system. The most crucial reaction derivable from the performance appraisal can be expected to be satisfied with the performance evaluation system.

Keeping and Levy (2000) argue that the perception of employees is probably the best criterion to evaluate a performance appraisal system further indicating that it would be inefficient if employees did not see it as fair, useful and equitable. Suliman (2007) argued that performance appraisal mechanism can only be effective if it is viewed as fair and reflective of actual performance by employees. Employees are believed to show a positive reaction towards their jobs if they perceive fair treatment of the appraisal system in the workplace (Crossman, 2004). Furthermore, according to Sabeen et al (2008) the employees' reaction towards the appraisal mechanism plays a crucial role in the overall job satisfaction.

Therefore, studying how the performance appraisal system of an organization is perceived by employees would have paramount importance to understand the problems associated with it. Various studies have been conducted to show the employees satisfaction with performance appraisal system. For instance, Pettijohn et al. (2001) conducted study to examine the attitudes of American federal employees toward performance appraisal and concluded that the majority of employees were dissatisfied with the way performance appraisal was conducted. When employees see how good they are performing and understand what performance goals they can achieve in future they tend to be motivated to improve their performance (Hannay, 2010 as in Selvarajan et al. 2011).

According to Fletcher (2001), employees' dissatisfaction with performance appraisal may signal a lack of success of performance appraisal as a mechanism for developing and motivating employees. There is a general agreement among performance appraisal researchers that assessment of appraisal reactions is important (Keeping and Levy, 2000). For example, it is frequently argued that in order for performance appraisal to positively influence employees' behaviour and future development, employees must experience positive appraisal reactions.

Feedback on performance appraisal is another important area where the employee perception can be influenced with regular and timely feedback on performance appraisal. According to Erdogan (2002), feedback is major factors which affect employee perception and is an important component of performance appraisal system. Employee perception about performance appraisal system will be positive if they know that the appraisal process is useful tool to get feedback which enables them to improve their performance (Mullins, 2007).In relation to study by Roberts (2003), performance appraisal feedback give a chance to an employee to identify the challenges related to his or her work achievements and helps them necessary adjustment for future improved performance.

Performance appraisal suggests that feedback richness which indicates the extent to which appraisals are frequent, timely, and specific can contribute to perceptions of appraisal fairness (Kinicki et al., 2004). Employee performance ratings serve as inputs to performance-based feedback and administrative decisions relating to promotion, training, and salary increases (Erdogan et al., 2001). Employees perceive feedback as a negative when feedback on poor performance is used as controlling and punishment (Poon, 2004).

Moreover, Fapohunda (2015) in his study indicated that academic staffs in Nigeria public Universities did not see their performance appraisal system as correct and fair enough since the entire job elements of their performance are not captured adequately.

When employees perceive their performance ratings to be fair and appropriate, they tend to accept their performance appraisal as a valid indicator of their performance and thus may have positive perception toward performance appraisal. Francis and Peter (2012) studied the employees' perception toward performance appraisal system of University of Cape Coast in Ghana and their finding indicated that employees of the University perceived that the performance appraisal system is affected by subjectivity of appraiser. In Samara University; academic staffs are appraised by students, peers, head of departments and college deans jointly. However, various studies indicated that academic staffs have diverse attitude toward appraisers.

For example, Severino and Newman (2011) concluded in their study that University lecturers had negative perception toward students' evaluation of their performance. This may be due the reason that students anticipated 
course grade and the students overall evaluation of the instructor concluding that instructors with generous grading standards receive higher overall performance ratings.

However, feedback from different sources can provide a clear picture of the employees overall performance and can be viewed as being fair as the rating is based on multiple sources (Williams, 2001). But, employees may dislike feedback from peers as it can be perceived as being based more on workplace friendships than actual performance (Miller, 2001).

Employees who receive performance ratings from multiple sources may be more willing to accept such ratings as fair when compared to ratings received from a single source (McCarthy and Garavan, 2007).Multi source rating may result in more distributive fairness compared to single-source ratings. Therefore, creating a multi source appraisal environment may ensure better procedural fairness compared to a supervisory appraisal, which is subject to bias. If a supervisor is biased or has some political objective, he/she may distort the procedures used in performance appraisal and thus a supervisor-only appraisal may lead to a lesser degree of procedural fairness.

This shows that if employees have low levels of trust for their appraiser, they may be less satisfied with the appraisal and may not readily accept feedback from that source. Thus, in a multi source appraisal environment, it is more probable that employees may perceive higher levels of interactive justice than in a single-source appraisal environment.

The need for this study stems from the dissatisfaction of the researcher, being a faculty member at Samara University, with the current performance appraisal system. Thus, the researcher was interested in exploring other academic staffs' perception regarding the current performance appraisal system and their possible suggestions for effective performance appraisal system. In the light of this, the researcher was interested in finding out academic staff satisfaction with performance appraisal system, perception of staff toward regular feedback provision and appraisers. This study is considered to shade light on improvements to be made and if properly implemented, will become an asset when responding to academic staffs as it should improve their growth and development.

Generally, employees are likely to accept and contribute meaningfully to a given performance appraisal system if they perceive it as an opportunity for promotion, and as a path for personal development, a chance to be visibly demonstrated skills and abilities. On the other hand, if employees perceive performance appraisal as an ineffective, biased and merely attempt by management to exercise closer supervision and control over employees' tasks, various reactions may result and counterproductive.

Therefore, it is very important that the University management must have the knowledge of the employees' perception toward performance appraisal system which would have paramount importance in making various improvements to make performance appraisal effective and fruitful. This study aimed at exploring the academic staffs' perception toward performance appraisal system of Samara University in general and specifically to examine academic staffs: Satisfaction with overall performance appraisal system of the University; attitude toward appraisal feedback, attitude toward the performance appraisers and finally, to provide recommendation based on the findings of the study.

\section{Objective of the Study:-}

The general objective of this study is to examine academic staffs' perceptions toward performance appraisal system in Higher Education: case of Samara University

Specifically:

1. To examine academic staffs of Samara University satisfaction with performance appraisal system.

2. To identify academic staffs opinion toward provision of performance appraisal feedback.

3. To identify academic staffs feelings regarding performance appraisal their appraiser.

\section{Significance of the Study}

This study would provide important information for all parties regarding how academic staffs are perceiving performance appraisal system in place and pave the way for further investigation by other researchers on why academic staffs are not satisfied with performance appraisal system and what should be done to make performance appraisal system more effective and useful for human resource decision -making. 


\section{Methodology of the Study:-}

For the purpose of this study, descriptive research design was employed since it is found appropriate to describe the perception of academic staff of Samara University regarding performance appraisal system. This study used both primary and secondary data. However, the study used primary data predominantly. As such, the primary data for the study were collected through structured questionnaire from academic staffs with two or more teaching experience in Samara University. The secondary data were collected from previous studies conducted by other researchers in related area of study and relevant websites. Respondents from seven colleges and one school of law with two and more years of teaching experience were included in this study. After stratifying the whole population into their respective college, proportional numbers of respondents were selected from each college and one school of law by using purposive sampling in order to select respondents with two or more teaching experience. Data collected was analysed using descriptive statistics through SPSS version 20.

Out of total of 968 academic staffs working in the University, 283 sample respondents were participated in filling structured questionnaire. Among sampled respondents, only 261 were filled and returned the questionnaires with the response rate of 92 percent which is highly acceptable. A breakdown of the sample size is presented in table 1 below:

Table 1:- Population and Sample Size.

\begin{tabular}{|l|l|l|l|}
\hline & College & Population & Sample size \\
\hline 1 & Business and Economics & 82 & 24 \\
\hline 2 & Social Science and Humanities & 201 & 59 \\
\hline 3 & Natural and Computational Science & 126 & 37 \\
\hline 4 & Veterinary Medicine & 41 & 12 \\
\hline 5 & Dry land and Agriculture & 120 & 35 \\
\hline 6 & Health Science & 94 & 27 \\
\hline 7 & Engineering and Technology & 274 & 80 \\
\hline 8 & School of Law & 30 & 9 \\
\hline & $\mathbf{9 6 8}$ & $\mathbf{2 8 3}$ \\
\hline
\end{tabular}

Source: Own Survey, 2019

Sample Size is determined by using Yemane's sample size determination formula as follows:

$\mathrm{n}=\mathrm{N} /\left(1+\mathrm{N}\left(\mathrm{e}^{\wedge} 2\right)\right)$ where

$\mathrm{N}=$ total number of population (academic staffs)

$\mathrm{n}=$ sample size

$\mathrm{e}=$ level of significance $(\alpha=5 \%)$

$\mathrm{n}=968 /\left(1+968\left(0.05^{2}\right)=968 / 3.42=283\right.$

Data Analysis and Discussion of Results

Frequency Distribution Analysis for Demographic Characteristics of respondents (Majority of the results)

The characteristics of respondents are described in the following table in terms of gender, age, academic rank and years of service.

Table 2:- Frequency Distribution Analysis for Demographic Characteristics.

\begin{tabular}{|l|l|l|l|}
\hline Characteristic & Majority & Frequency & Percentage \\
\hline Gender & Male & 234 & 89.7 \\
\hline Age & $26-35$ & 198 & 75.9 \\
\hline Academic rank & Lecturer & 190 & 72.8 \\
\hline Years of experience & 3-8 years & 154 & 59 \\
\hline
\end{tabular}

Source: Own Survey, 2019

As indicate in the table 2 above, regarding gender of the respondents $243(89.7 \%)$ were males and the remaining $27(10.3 \%)$ respondents were found females indicating the University's academic staffs majorly composed of males. The greater number of respondents belongs to the age groups between 26-35 years i.e., 198 (75.9\%). Most of the respondents were having academic rank of lecturer which account for $190(72.8 \%)$. The academic ranks of the respondents may indicate that though Samara University is recently established it has to give more attention to academic staff development in order to sustain the quality of education. With regard to teaching experience in the 
Samara University, most of the respondents found having teaching experience of between 3 to 8 years i.e., $154(59 \%)$ followed by respondents who served for 2 years i.e., 62(23.8\%) .

\section{Academic staff Satisfaction with performance appraisal system}

Studies by Pettijohn et al. (2001) and Aleassa (2014) indicated employees were dissatisfied with performance appraisal system. Similarly, finding of this study as shown in the table 3 below indicated that majority of the respondents i.e., $162(62.1 \%)$ academic staffs of Samara University were not satisfied with the current performance appraisal system. This could because of lack of feedback, fairness and lack of participation in creation and implementation of performance appraisal system. Another reason of dissatisfaction may be poor recognition and reward attached to performance appraisal.

Table 3:- Respondents overall satisfaction with performance appraisal system.

\begin{tabular}{|l|l|l|l|l|l|}
\hline \multicolumn{2}{|c|}{} & Frequency & Percent & Valid Percent & Cumulative Percent \\
\hline Valid & Agree & 81 & 31.0 & 31.0 & 31.0 \\
\cline { 2 - 6 } & Neutral & 18 & 6.9 & 6.9 & 37.9 \\
\cline { 2 - 6 } & Disagree & 126 & 48.3 & 48.3 & 86.2 \\
\cline { 2 - 6 } & Strongly Disagree & 36 & 13.8 & 13.8 & 100.0 \\
\cline { 2 - 6 } & Total & 261 & 100.0 & 100.0 & \\
\hline
\end{tabular}

Source: Own Survey, 2019

\section{Attitude toward performance appraisal feedback}

A performance appraisal must be implemented in almost every organization, because it is quite impossible to achieve the desired organizational goals without having an accurate and on-time performance feedback. The absence of feedback leads to difficult of identifying the changes needed (Watkins and Leigh, 2010) .When it is well designed and well implemented, the feedback will be usefully for improving employees performance.

According to study by Wesley, D. E. (2004), slightly more than two-third of the respondents believes that there is low feedback rate in the performance appraisal process. Consistent with study finding by Wesley, D.E (2004), feedback is as important as the conducting the appraisal. Without feedback most workers will lose confidence in the performance appraisal system since they will not be able to identify it with their developments and future improvements.

Table 4:- Respondents attitude toward performance appraisal feedback.

\begin{tabular}{|l|l|l|l|l|l|}
\hline Descriptive Statistics & N & Minimum & Maximum & Mean & Std. Deviation \\
\hline $\begin{array}{l}\text { Each semester, I receive regular } \\
\text { feedback on my performance }\end{array}$ & 261 & 1 & 5 & 3.28 & 1.286 \\
\hline $\begin{array}{l}\text { My department provides positive } \\
\text { feedback for good performance than } \\
\text { criticizing poor performance }\end{array}$ & 261 & 2 & 5 & 3.48 & 1.195 \\
\hline Valid N & 261 & & & & \\
\hline
\end{tabular}

Source: Own Survey, 2019

Though necessarily, feedback is the outcomes of performance appraisal as it is supposed to indicate the weakness and strength, one can see as it is observed in above table 4 with an average response mean of 3.28 which indicate majority of the respondents responded that feedback regarding their performance appraisal is not regularly provided each semester. On the other hand, majority of the respondents (average mean of 3.48) disagreed that their department do not provide positive feedback for good performance than criticizing poor performance. This situation has a far - reaching effect in several aspects. Firstly, for example, there is no performance based discrimination among the academic staffs such as performance based recognition and promotion. Secondly, had there been regular feedback the staffs could have updated their knowledge, skill and attitude as well as developed self -confidence and work for further future improvements.

Moreover, lack of feedback may imply that the academic staffs were appraised for the sake of appraising them without counselling and at least providing recognition or reward. If staffs are not provided with feedback, 
recognition or rewards to the minimum, this may lead them to lower performance because denying recognition and failure to praise the good performance is praising poor performers.

\section{Attitude toward performance appraisal appraisers}

Respondents may diverse attitude toward those who are appraising their performance.

Table 5:- Respondents' attitude toward their performance appraisers.

\begin{tabular}{|l|l|l|l|l|l|}
\hline Descriptive Statistics & $\mathrm{N}$ & Minimum & Maximum & Mean & Std. Deviation \\
\hline $\begin{array}{l}\text { My students evaluation in each semester on } \\
\text { average reflects my real performance }\end{array}$ & 261 & 1 & 5 & 3.38 & 1.159 \\
\hline $\begin{array}{l}\text { I believe my peers evaluation is fair and } \\
\text { appropriate }\end{array}$ & 261 & 1 & 5 & 2.78 & 1.302 \\
\hline $\begin{array}{l}\text { My performance evaluation by the dean and } \\
\text { head of department is show my } \\
\text { real contribution to department and college }\end{array}$ & 261 & 1 & 5 & 3.04 & 1.338 \\
\hline Valid N & 261 & & & & \\
\hline
\end{tabular}

Source: Own Survey, 2019

In Samara University, academic staffs are evaluated by students, peers and jointly by academic dean and head of department which accounts for 50\%, 15\% and 35\% respectively. In this regard, respondents were asked about the fairness and appropriateness of appraisers which include students, peers, head of departments and college deans. An average response mean of 3.38 regarding students evaluation indicates that academic staffs did not believe students evaluation reflect their actual performance and not fair. Additionally, with regard to peers evaluation fairness and appropriateness as well as evaluation by head of departments and deans jointly respondents were neutral indicated by an average mean of 2.78 and 3.04 respectively. The reason that one can see this indifference and a slight disagreement towards peers, head of departments and college deans is may be due to lack of feedback of performance appraisal.

\section{Conclusion:-}

The primary aim of this research paper was to identify academic staffs' perception toward performance appraisal in general and specifically, academic staffs' satisfaction with the performance appraisal practice, staffs feeling toward feedback provision, and finally attitude toward performance appraisers in Samara Univeristy.

Based on the findings as summarized above, the study concludes that $89.7 \%$ of the respondents were male. It was therefore concluded that, the likelihood of a staff being a male is higher than the probability of being a female. Again, with respect to their age, it was found that majority of them were aged between 26 and 35 years showing that majority of Samara University academic staffs are young adults. Regarding the number of years they had spent with the University, $72.8 \%$ had spent between 3 and 8 years 10 years as staff of Samara University.

Most academic staffs of Samara University were found dissatisfied with the performance appraisal system which indicate that more detailed study should be made to know why academic staffs show dissatisfaction toward performance appraisal.

Regarding provision of performance appraisal feedback, the study result indicated that feedback was not given on regular basis at end of each semester which show academic staffs cannot know their strength and weakness and unable to make improvement for the future. If timely feedback is not given, appraising staffs will simply remain paperwork. With regard to this, various studies indicated that lack of feedback is the major in performance appraisal process.

Moreover, academic staffs of Samara University were not satisfied with appraisers evaluation of their performance may be due the reason that students do not evaluate teachers based on their performance rather they evaluate teachers based on the score obtained in the subject thought by teachers or due to lack of awareness toward the benefits of performance appraisal. This is consistent with the experience of the researcher; it is observed that in 
Samara University students rating is characterized by highly rating faculty who gave higher score than a teacher who gave lower grade for students.

Besides, majority of the respondents found that they are indifferent with performance appraisal by head of departments and their respective deans may be due to the lack of transparency both during the evaluation and after evaluation, lack of clarity of performance evaluation criteria and the subjectivity involved in the evaluation, subjective nature of the standards against which the performance of employees are judged lead raters to manipulate the evaluation for their own personal agendas or raters evaluate the performance of employees on the basis of recent behaviours.

\section{Recommendation and practical implications for future research Recommendation:-}

Based on the research results, first it can be noticed that having effective performance in this University will be very beneficial and important. The first recommendation for the University is to have clear and participatory performance appraisal policy in which academic staffs clearly know the purpose of performance appraisal since there is no policy of appraisal currently. Secondly, there should be fair and regular performance appraisal feedback so that employees know their strength and weakness and keep up with strength and improve weakness, high performance should be recognized and rewarded in order to increase its perceived fairness otherwise it would be meaningless to show commitment and high performance by academic staffs unless there is performance based discrimination.

Thirdly, awareness about the benefit of performance to appraiser especially students would be better to increase awareness regarding the use and importance of performance evaluation in the University in sustaining the quality of education. Above all, further study could be made to understand why academic staffs were dissatisfied with performance appraisal system of the University.

Finally, support from top management must be there for the successful implementation of performance appraisal because Watkins and Leight (2010) argued that the best time to apply a performance management system in an organization is when the organizational leaders are ready to fully integrate it into the management functions of the organization. Everyone in the University must be committed to provide every support and all the information needed, because a poorly implemented appraisal system can do more harm than good. It would be important to identify the needs and gaps that need to be changed for the effective implementation of appraisal system.

\section{Further Research Recommendations}

The results of this research, even though valuable, cannot be considered as valid for every higher education institutions. Further research can be performed to other higher education institutions in different locations to generalize the research results. Moreover, only few aspects of performance appraisal have been studied such feedback provision, attitude toward appraiser and academic staffs satiation. Therefore, it would be important to include more attributes to examine academic staff perception toward performance appraisal system.

\section{Acknowledgements:-}

I am very grateful to all academic staffs of Samara University who were participated in this study by filling questionnaire and providing genuine and relevant information by taking time of their busy schedule. I want to thank everybody who assisted in any way to the success of this study. My gratitude goes to you all.

\section{References:-}

1. Aleassa, H.M. (2014): Performance Appraisal Satisfaction and Counterproductive Behaviours: Direct and Moderating Effects, International Journal of Business Administration, 5(1), 76- 89.

2. Ambreen, A., Kausar, Y., Bashir, K.(2011):Performance Appraisal Systems in Public Sector Universities of Pakistan. International Journal of Human Resource Studies, ISSN 2162-3058, 2011, Vol. 1, No. 1.

3. Crossman, A. (2004): Satisfaction with Performance Appraisal Systems. Journal of Managerial Psychology. 19(5): 526-541.

4. Erdogan, B. (2002): 'Antecedents and Consequences of Justice Perceptions in Performance Appraisals'. Human Resource Management Review, 12(4), 555-578. 
5. Erdogan, B., Kraimer, M.L., and Liden, R.C. (2001): 'Procedural Justice as a Two-Dimensional Construct: An Examination in the Performance Appraisal Context'. The Journal of Applied Behavioural Science, 37, 2, 205222.

6. Fapohunda, M. (2015): Dimensions of University Academic Staff Performance Appraisal in Selected Public Universities in Nigeria. Journal of Global Economics, Management and Business Research, 3(3): 139-147, 2015

7. Fletcher, C. (2001): Performance Appraisal and Management: The Developing Research Agenda. Journal of Occupational and Organizational Psychology, 74, 473-487.

8. Francis, O. and Peter, A. (2012): Employees' Perception of Performance Appraisal System: A Case Study. International Journal of Business and Management, Vol. 7, No. 2; January 2012.

9. Jafari, M., Bourouni, A., Amiri, R.H, (2009): A New Framework for Selection of the Best Performance Appraisal Method, European Journal of Social Sciences - Volume 7, Number 3

10. Jawahar, I. M. (2007): The Influence of Perceptions of Fairness on Performance Appraisal reactions. Journal of Labor Research, 28(4), 735-754.

11. Keeping, L. M., and Levy, P. E. (2000): Performance appraisal reactions: measurement, modeling, and method bias. Journal of Applied Psychology, 85(5), 708-723.

12. Kinicki, A.J., Prussia G.E., Bin W., and McKee-Ryan, F.M. (2004): A Covariance Structure Analysis of Employees Response to Performance Feedback. Journal of Applied Psychology, Vol. 89, No. 6, Pp. 1057-1069.

13. Kuvaas, B. (2007): Different Relationships between Perceptions of Developmental Performance Appraisal and Work Performance. Personnel Review, 36(3), 378-397.

14. Kuvaas, B. (2011): The Interactive Role of Performance Appraisal Reactions and Regular Feedback. Journal of Managerial Psychology, 26 (2), 123-137.

15. Levy, P.E. and Williams. J.R. (2004): The Social Context of Performance Appraisal: A Review and Framework for the Future. Journal of Management, Vol. 30, No. 6, pp. 881-905.

16. Liza, E.D. (2012): Performance Appraisal System: It's Implication to Employee Performance. International Journal of Economics and Management Sciences Vol. 2, No. 3, 2012, pp. 55-62.

17. McCarthy, A., \& Garavan, T. (2007). 360 degree feedback process, improvement and career development. Journal of European Industrial Training, 25, 1- 5.

18. Miller, J.S. (2001):Self-monitoring and performance appraisal satisfaction: An exploration study. Human Resource Management, 40(4), 321-332.

19. Mullins, J.L. (2007): Management and Organizational Behavior (8th edn.).Edinburgh Gate, UK: Prentice Hall; Financial Times.

20. Patrick, H. I. and Ali, O. (2014): Perception of Justice in Performance Appraisal and Effect on Satisfaction: Empirical Findings from Northern Cyprus Banks. Procedia Economics and Finance 23 (2015) 964 - 969.

21. Pettijohn, L. S., Parker, R. S., Pettijohn, C. E., and Kent, J. L. (2001):Performance Appraisals: Usage, Criteria and Observations. Journal of Management Development, 20(9), 754.

22. Poon, J. M. L. (2004): Effects of Performance Appraisal Politics on Job Satisfaction and Turnover Intention. Personnel Review, 33(3), 322-334.

23. Rasch L. (2004): Employee Performance Appraisal and the 95/5 Rule Community College Journal of Research and Practice, 28:5,407-414.

24. Roberts, G. E. (2003): Employee appraisal system participation: A technique that works. Public Personnel Management, $32(1), 89$.

25. Sabeen, Z., Mehboob, S.A., Muhammad, A. (2008): Perceived Fairness of and Satisfaction with Employee Performance Appraisal and Its Impact on Overall Job Satisfaction. The Business Review, Cambridge. Vol. 10, No. 2.

26. Selvarajan, R.and Cloninger, P.A. (2008):The Importance of Accurate Performance Appraisals for Creating Ethical Organizations .Journal of Applied Business Research, 3rd quarter, Vol. 24, No. 3, pp. 39-44.

27. Selvarajan, S. T. and Cloninger, P. A. (2011): Can performance appraisals motivate employees to improve performance? A Mexican study. The International Journal of Human Resource Management, 23(15), 30633084.

28. Severino,M. and Newman,W. (2011): University Lecturers' Perception of Students Evaluation of their Instructional Practices: Waiter Sisulu University, Center for Learning and Teaching Department, Republic of South Africa.

29. Sonal Agarwal and Isaac Doku (2016): Performance Appraisal on Job Performance in the Tema Metropolitan Mutual Health Insurance Authority. International Journal of Business \& Management, ISSN 2321-8916, Vol 4, Issue 3. 
30. Suliman, A. M. T. (2007): Links between Justice, Satisfaction and Performance in the Workplace: A Survey in the UAE and Arabic context. Journal of Management Development, 26(4), 294-311.

31. Watkins, R. and Leigh, D. (2010): Handbook of Improving Performance in the Workplace. Volume 2: Selecting and Implementing Performance Interventions, International Society for Performance Improvement.

32. Wesley, D. E. (2004). Subordinate influence and the performance evaluation process: Test of a model. Organizational behaviour and human decision processes, 58(1), 101-135.

33. Williams, R.S. (2001): Managing employee performance: Design and implementation in Organization ( $2^{\text {nd }}$ ed.), London England: Thomson Learning. 